\title{
Energy and Emissions Conflicts in a Globalized World: The Asian and BRICS Case Studies
}

\author{
Touria Abdelkader-Benmesaud Conde ${ }^{1, *}$, Fernando Barreiro-Pereira ${ }^{2}$ \\ ${ }^{1}$ Universidad Nacional de Educacion a Distancia (UNED University), Madrid, Spain. \\ ${ }^{2}$ Department of Analisis Economico, Universidad Nacional de Education a Distancia (UNED University), Faculty of Economics and \\ Business Administration, 11 Paseo Senda del Rey, 28040 Madrid, Spain.
}

\begin{abstract}
How to cite this paper: Touria Abdelkader-Benmesaud Conde, Fernando Barreiro-Pereira. (2021) Energy and Emissions Conflicts in a Globalized World: The Asian and BRICS Case Studies. Journal of $\mathrm{Hu}$ manities, Arts and Social Science, 5(1), 23-34.

DOI: $10.26855 /$ jhass.2021.01.004
\end{abstract}

Received: December 21, 2020

Accepted: January 15, 2021

Published: February 4, 2021

${ }^{*}$ Corresponding author: Touria Abdelkader-Benmesaud Conde, Universidad Nacional de Educacion a Distancia (UNED University), Madrid, Spain. Email: tabdelkader@madrid.uned.es

\begin{abstract}
The main aim of this paper is to observe the environmental behavior in some countries of the world, focusing the study on the Asian case, by analyzing the trend of the energy consumption and emissions indicators in each country.The pollutants that contribute most to environmental degradation are carbon dioxide emissions and PM10 suspended particles. In 41 years, from 1971 to 2012, greenhouse gas emissions have doubled, with $\mathrm{CO}_{2}$ accounting for two thirds of greenhouse gas emissions. The aim of this research is to analyse to what extent the excess of $\mathrm{CO}_{2}$ emissions is directly associated with energy consumption or are due to imperfections in production processes. In order to carry out this analysis, a microeconomic specification has been carried out, which has been applied by using econometric techniques across some Asian countries and also some metropolitan areas, considering IEA (2016) annual data. Only carbon dioxide emissions are addressed in this paper, but it does not address other emissions such as $\mathrm{NO}_{\mathrm{x}}$ or $\mathrm{SO}_{\mathrm{x}}$. The paper relates issues to central questions of international politics and theoretical debates concerning to the levels of energy consumption, carbon dioxide emissions and the role of the renewable energies on the climate change and the wellbeing of the consumers. The paper also examines some conflicts coming from competition for energy resources, energy dependence and the spillover effects of the emissions on the proper and neighboring areas.
\end{abstract}

\section{Keywords}

Emissions, Renewable Energy, Cities, Economic Conflicts, Political Conflicts

\section{Economic introduction to the Asian countries}

The environment is an area of complex study where physical, chemical, biological, cultural and social factors are involved and related, and where the hand of man is omnipresent. The environment becomes part of a globalized world. The involvement of every continent, country, city, or village is important for managing and channelling energy resources, and use of them must be made in the most optimal way possible. Much has been done and written about the use of energy resources produced in each location: how to get them, exploit them, treat them, use them, recycle and manage waste. But when a man hits on the environment, the environment, in turn, impacts on man by air pollutants, water and earth, causing sometimes illness and even deaths. Technology is an important factor to obtain a better management of energy resources. Increased technology is usually associated with less pollution, and the application of technology can solve some environmental problems associated with technological development. The problem associated with the global overpopulation is a factor to consider in terms of environment and waste aggression. We 
will focus on the air pollution and its impact on cities and megacities in terms of pollution, health, potential border disputes; and possible solutions.

Asian countries, have a large population, estimated in more of $40 \%$ of the world population; an extensive territory; a lot of natural resources; common views on global economic problems; a very high growth of its gross domestic product, estimating a joint GDP of approximately 135 billion dollars, and participation in world trade in recent years, being countries very attractive to investors. The World Bank's requirement to promote equality among countries and greater participation in the International Monetary Fund and the obtaining of concessions for the granting of intellectual property rights have been common objectives at the economic-political level. Asian countries, are dominant global providers of technology and services, Russia become dominant as suppliers of raw materials, including food, with a large increase in their industrial resources. These countries may form a powerful economic bloc. To can compete, these countries must obtain greatly strengthened education, direct investment, internal consumption and spirit of domestic enterprise. According to the study, the Asian countries, especially India and China, have the fastest growth potential among the countries for the next 30 years. An important reason for that is the decline in the working-age population.

India is considered as the third world energy power, since it produces coal, biofuels and waste, crude oil and natural gas. Its majority consumption is in biofuel, oil products, coal, electricity and natural gas. India has been involved in the use of renewables betting on wind and solar energy. China is today the first energy power in the world, but above all in the development of renewable energy. The production of coal, crude oil, bio-fuels, hydro and nuclear is still very prominent, but it is betting very strongly on wind energy, solar photovoltaic and thermal, geothermal and marine energy. Russia produces natural gas, crude oil, coal, nuclear energy and hydro, in this order, being its majority consumption natural gas, oil products, heat and electricity. The great extension of Russia allows the development of renewable energies, being the most developed the geothermal energy, followed by solar and wind energy. Its consumption coming from coal, oil products, electricity, natural gas, biofuel, heat and renewable energy.

In this research, only the $\mathrm{CO}_{2}$ emissions caused by energy consumption and the processes of production of goods and services are analysed. The relationship between emissions and energy consumption, as well as the relationship between energy consumption and output, or output growth, has been extensively analysed since the work of Kraft and Kraft (1978), from which a great deal of research on this subject is derived, but there is still no precise consensus as to the relationship between energy consumption and economic growth. In this sense, two opposite positions can be identified: the first maintains that changes in energy consumption do not have a clear effect on economic growth and, the second, that there is some relationship between energy consumption and the level of production. Enough studies have tried empirically to prove this relationship in economies such as the United States (Abosedra \& Baghestani, 1989; Gardner \& Joutz, 1996; Soytas, Sari, \& Ewing, 2007); Canada (Ghali, 2004); Mexico (Caballero \& Galindo, 2007; Gómez, 2010); Central America and Caribbean countries (Apergis \& Payne, 2009). Studies in Asian countries have been carried out by Razzaqi, et al. (2011); specifically in Bangladesh (Alam, et al., 2012); China (Zhang \& Cheng, 2009) in the period 1960-2007; Taiwan (Cheng, 1997) over the period 1980-2007; Pakistan (Siddiqui, 2004); Iran (Zamani, 2007); India (Mallick, 2009); Turkey (Jobert \& Karanfil, 2007) and Halicioglu (2009) for the period 1960-2005; and Ang (2007a) examines the relationship between GDP, pollutant emissions and energy consumption in Malaysia between 1971 and 1999. In Africa, Belloumi (2009) examines the causal relationship between energy consumption per capita and GDP per capita in Tunisia, for the period 1971-2004. Studies in European countries have been carried out in France (Ang, 2007b), Greece (Tsani, 2010), Russia (Zhang, 2011) and in Spain (Labandeira, et al., 2017). Some analysis performed for groups of countries have been carried out by Medlock and Soligo (2001) on 28 countries of different levels of development, Pao and Tsai (2010) that examine the relationships between $\mathrm{CO}_{2}$ emissions, energy consumption and the GDP in the BRICS countries during the period 1990-2005; Mehrara (2007), which examines the causality between energy consumption per capita and GDP per capita through panel data on eleven oil exporting countries; Luzzati and Orsini (2009), who study the relationship between energy consumption and GDP per capita in 113 countries for the period 1971-2004 and Farhani and Ben Rejeb (2012) who conducted a study for 90 countries. Other research argues that increases in GDP increase pollution until the country reaches a certain per capita income, from which pollution begins to decrease (Hettige, Mani, \& Wheeler, 2000). In addition to all these authors, Srnivasan and Siddanth (2015) also found relationships between energy consumption and the level of production, which does not happen in the investigations of Yu and Choi (1992), Altinay and Karagol (2004).

The structure of this article is as follows: The modelling of the equations that try to explain the causal relationship between energy consumption and production and between $\mathrm{CO}_{2}$ emissions and energy consumption are carried out in 
Section 2. Section 3 contains the results obtained from the estimates of the equations obtained in the second section. Section 4 analyse the effects of air pollution on some Asian cities and finally, Section 5 contains the most relevant conclusions of this research.

\section{A microeconomic model for energy consumption}

Although a prediction model is not the same as a causal model, a prediction model must be designed based on the past data and available theory. If such a theory does not exist, then the prediction model will be based only on the sequence of historical data. But respect to demand functions, and hence demand of energy, theory exists. And not only the theory exist, but also the econometric specification for a linear regression model, as is the case of the linear demand systems or almost ideal demand systems (Deaton \& Muellbauer, 1980). The theoretical specification of energy demand is very simple: Energy is a consumption good and at the same time a production factor, with a behavior similar to that of land.

\subsection{Simplifying Hypotheses}

Suppose then that in the economy there are a small number $F$ of oligopolistic companies in charge of supplying energy to the population, $H$ consumers and a large number $N$ of firms that for simplicity we assume in perfect competition. By assuming no political or governmental intervention, being $e$ quantity of energy and $c$ and $R$ respectively the sets of goods and production factors different from the energy and $p_{e}, p_{c}$ and $p_{R}$ its respective unitary prices, assuming by simplicity Cobb-Douglas utility function:

$$
U(e, c)=e^{\alpha} c^{1-\alpha}
$$

And knowing that $m$ is the consumer monetary income or monetary per capita income and $P$ the general level price of the $\mathrm{X}$ goods, if each firm produces a similar good $X$, the behaviour of the individual agents in each period will be the following:

\subsection{Consumer behaviour}

It consists in to maximize the utility subject to the budget constraint:

$$
\operatorname{Max}\left\langle U(e, c)=e^{\alpha} c^{1-\alpha}\right\rangle \text { subject to: } p_{e}+p_{c}=m .
$$

Solving this maximization, we have: $m=\frac{p_{e}}{\alpha} e$, but $H m=Y$ (total monetary income), hence $Y=\frac{p_{e}}{\alpha} H e$. Therefore, the aggregate demand of energy as consumption good will be:

$$
H e=\frac{\alpha Y}{P_{e}}
$$

\subsection{Firms behaviour}

It consist in to maximize the profit to shell the good X, by assuming that the production function of the $\mathrm{X}$ good has a Cobb-Douglas features:

$$
X=A e^{\beta} R^{1-\beta}
$$

where $\mathrm{A}$ is the technical progress coefficient or total factor productivity. The producer problema is:

$$
\operatorname{Max}\langle\text { Benefit }\rangle=\operatorname{Max}\left\langle P A e^{\beta} R^{1-\beta}-p_{e} e-p_{R} R\right\rangle
$$

From the first condition for maximizing benefit (B), we have:

$$
B_{e}^{\prime}=0=\beta P A \frac{e^{\beta}}{e} R^{1-\beta}-p_{e}=\frac{\beta P X}{e}-p_{e}=0
$$

Hence: $e=\frac{\beta P X}{P_{e}}$. The aggregate demand of energy as production factor will be then:

$$
N e=\frac{\beta Y}{P_{e}}
$$

And the total energy demand $\left(E_{D}\right)$ :

$$
E_{D}=H e+N e=(\alpha+\beta) \frac{Y}{P_{e}}
$$




\subsection{Energy supplier companies}

We will assume that energy supply companies, which generally are oligopolistic companies, are similar and, by simplicity, have a quadratic cost function of type:

$C=p_{R} R+\frac{1}{2} e^{2}$. Then, the unit price to which they sell the energy $\left(p_{e}\right)$ is imposed by a mark-up $(\mu>1)$ on their marginal costs: $p_{e}=\mu C^{\prime}{ }_{e}$, that is: $p_{e}=\mu e$. Hence: $p_{e} F=\mu(F e)$. But $F e$ is the total energy supplied $\left(E_{S}\right)$ by all companies in the global market and therefore:

$$
E_{S}=\frac{P_{e} F}{\mu}
$$

\subsection{Equilibrium:}

Equalling supply and demand of energy, $E_{S}=E_{D}=E$, by means of the equations 8 and 9 we have that:

$$
E=\frac{p_{e} F}{\mu}=(\alpha+\beta) \frac{Y}{p_{e}}
$$

but from the first part of equation 10, or form 9, we know that the enegy price is: $p_{e}=\frac{\mu E}{F}$ and substituting this result in the second par of the equation 10 we will know the total consumption of energy in the market: $E^{2}=$ $\frac{(\alpha+\beta) F}{\mu} Y$. And so-calling $\frac{(\alpha+\beta) F}{\mu}$ as $\lambda^{2}$, we have that:

$$
E=\lambda \sqrt{Y}
$$

And taking natural logarithms: $\log _{e} E=\log _{e} \lambda+\frac{1}{2} \log _{e} Y$. Generalizing it, the final equation to be estimate for energy consumption is:

$$
\log _{e} E=\gamma_{0}+\gamma_{1} \log _{e} Y+\varepsilon
$$

where $E$ is the effective energy consumption and $Y$ the nominal income or GDP at current prices. The term $\gamma_{0}$ must collect the rest of the explanatory variables including the intercept parameter and climatic variables. Another econometric specification may come from the breakdown of nominal income into its two components:

$$
\log _{e} E=\gamma_{0}+\eta_{1} \log _{e} y+\eta_{2} \log _{e} P+\varepsilon
$$

where $y$ is now the real income or GDP at constant prices. If the period for the forecast horizon were longer it would have to resort to growth models. By assuming that the growth model was neoclassical and by assuming that energy is a cumulative factor without depreciation rate, then at the steady state we will have that:

$$
E=\left(\frac{s}{n+g}\right) y
$$

being $y$ the real income, $s$ the saving rate, $n$ the population growth rate and $g$ the technology growth rate.

Suppose now that a percentage of the contaminant emissions $(E m)$ are coming from energy consumption (E); then: $E m=\rho E^{\Theta}$, where $\rho$ and $\Theta$ are parameters. Taking natural logarithms we have: $\ln (E m)=\ln \rho+\Theta \ln E$. Hence, we have found the following lognormal relatinship between emissions $(E m)$ and energy consumption $(\mathrm{E})$ :

$$
\log _{e}(E m)=\vartheta_{0}+\vartheta_{1} \log _{e} E+\varepsilon
$$

to estimate.

\section{Data and empirical results for emission impacts}

A large series of estimates have been made relating energy consumption to nominal GDP, as well as the relationship between carbon dioxide emissions with the energy consumption. The ratio between emissions and energy consumption gives us a value that if it turns out to be greater than the ratio between energy consumption and GDP, would indicate a great use of fossil fuels and great emissions that would affect proper cities and even neighboring countries, affecting the health of the people exposed to these emissions. On the other hand, if the relationship between emissions and energy consumption turns out to be lower than the ratio between consumption and GDP, it would indicate that fossil fuels are being replaced by alternative and renewable or green energies without or small pollution.

Based on the model developed in Section 2, an application has been made with data of the five BRICS countries in a period between 2000 and 2015, with annual data collected in the IEA (2016). The equation that is applied as the first estimate is equation (12) that relates the consumption of energy with nominal GDP, that is, how much the nominal 
GDP consumption depends; then the equation (15) that relates the carbon dioxide emissions to the energy consumption is applied as a second estimate, that is, how much CO2 emissions depend on the energy consumption. The estimation of these both relationships are collected in Table 1 and Table 2. In Table 1, the dependent variable is the natural logarithm of the total energy consumption by country, represented by $\ln E$ and the independent variable used is the natural logarithms of the nominal GDP of each country. We have compared with some economically and energetically emerging countries like Brazil or South Africa.

Table 1. Estimation of the relation between energy consuption and GDP (2000-2015)

\begin{tabular}{|c|c|c|c|c|c|}
\hline & Brazil & Russia & India & China & South Africa \\
\hline \multicolumn{6}{|c|}{$\begin{array}{l}\text { Dependent variable: } \\
\qquad \ln (\mathrm{E})\end{array}$} \\
\hline Intercept & $\begin{array}{c}10,824.3 \\
(1.21)\end{array}$ & $\begin{array}{l}349,596.0 \\
(9.71)\end{array}$ & $\begin{array}{l}166,459.0 \\
(9.74)\end{array}$ & $\begin{array}{l}517,456.0 \\
(3.99)\end{array}$ & $\begin{array}{l}24,764.8 \\
(6.32)\end{array}$ \\
\hline $\ln$ GDP & $\begin{array}{c}91.64 \\
(20.40)\end{array}$ & $\begin{array}{l}58.72 \\
(2.37)\end{array}$ & $\begin{array}{l}181.51 \\
(16.74)\end{array}$ & $\begin{array}{c}162.36 \\
(7.27)\end{array}$ & $\begin{array}{l}118.89 \\
(10.63)\end{array}$ \\
\hline \multicolumn{6}{|l|}{ Tests } \\
\hline R2-adj. & 0.99 & 0.60 & 0.98 & 0.94 & 0.97 \\
\hline DW & 2.02 & 2.52 & 3.31 & 1.99 & 3.40 \\
\hline
\end{tabular}

t-ratios in brackets

Source: own elaboration.

In the estimation collected in Table 2, the dependent variable is the total emissions per country, represented by Em and the independent variable used is the energy consumption, represented by E, both in natural logarithms.

Table 2. Estimation of the relation between emissions and energy consumption (2000-2015)

\begin{tabular}{|c|c|c|c|c|c|}
\hline & Brazil & Russia & India & China & South Africa \\
\hline \multicolumn{6}{|c|}{$\begin{array}{l}\text { Dependent variable: } \\
\qquad \ln (E m)\end{array}$} \\
\hline Intercept & $\begin{array}{l}-26.80 \\
(-0.31)\end{array}$ & $\begin{array}{c}1,497.85 \\
(1,877.26)\end{array}$ & $\begin{array}{c}-552.88 \\
(-8.34)\end{array}$ & $\begin{array}{c}-956.88 \\
(-2.39)\end{array}$ & $\begin{array}{c}-156.96 \\
(-1.55)\end{array}$ \\
\hline $\ln E$ & $\begin{array}{l}0.0020702 \\
(4.53)\end{array}$ & $\begin{array}{l}0.0000053 \\
(2.88)\end{array}$ & $\begin{array}{l}0.0045554 \\
(30.66)\end{array}$ & $\begin{array}{l}0.0053263 \\
(18.99)\end{array}$ & $\begin{array}{l}0.0080303 \\
(5.27)\end{array}$ \\
\hline \multicolumn{6}{|l|}{ Tests } \\
\hline R2-adj. & 0.86 & 0.70 & 0.99 & 0.99 & 0.89 \\
\hline DW & 2.22 & 2.72 & 2.80 & 2.29 & 2.00 \\
\hline
\end{tabular}

t-ratios in brackets

Source: own elaboration

In these two regressions, the estimated parameters of the coefficients for ln GDP and ln E mind respectively the elasticity of the energy consumption (E) respect to the GDP, and the elasticity of the emissions with respect to energy consumption. That is respectively:

$$
\frac{\partial \ln E}{\partial \ln Y}=\frac{\Delta E / E}{\Delta Y / Y}=\varepsilon_{E, Y}, \text { and } \frac{\partial \ln ((E m)}{\partial \ln E}=\frac{\Delta E m / E m}{\Delta E / E}=\varepsilon_{E m, E}
$$

The product of $\varepsilon_{E, Y}$ by $\varepsilon_{E m, E}$ is equal to $\frac{\Delta E m / E m}{\Delta Y / Y}=\varepsilon_{E m, Y}$.

This allow us to compare the emission growth rate in relation to the nominal income and energy consumption growth rates. When comparing the growth rates, it will be possible to observe what causes more number of emissions, whether the consumption of energy or the nominal product of economic activity. The values of the elasticity $\varepsilon_{E m, Y}$ for each country are: Brazil: 0.1897; Russia: 0.0003; India: 0.8259; China: 0.8638; South Africa: 0.9547. The values of the elasticity $\varepsilon_{E m, E}$ for each country are: Brazil: 0.0021; Russia: 0.000005; India: 0.0045; China: 0.0053; South Africa: 0.0080 . 
Table 3. Estimation of the relation between elasticity $\varepsilon_{\mathrm{Em}, \mathrm{Y}}$ and elasticity $\varepsilon_{\mathrm{Em}, \mathrm{E}}(\mathbf{2 0 0 0 - 2 0 1 5 )}$

\begin{tabular}{cccccc}
\hline & Brazil & Russia & India & China & South Africa \\
\hline$\varepsilon_{E m, Y}$ & 0.1897 & 0.0003 & 0.8259 & 0.8638 & 0.9547 \\
$\varepsilon_{E m, E}$ & 0.0021 & 0.000005 & 0.0045 & 0.0053 & 0.0080 \\
\hline
\end{tabular}

Source: own elaboration.

As we can observe in Table 3, the values of the elasticity $\varepsilon_{E m, Y}$ are greater than the values of $\varepsilon_{E m, E}$, indicating that the greater emissions come from the all production are more higher than of which coming from the consumption of energy. By countries, there is greater pollution by energy production in South Africa, followed by China, India, Brazil and Russia. In a much smaller proportion and by countries, there are a greater number of emissions per energy consumption in South Africa, followed by China, India, Brazil and Russia.

\section{Effects of air pollution on cities}

Air pollution has negative influences in the environment and in humans. Increasing the carbon dioxide concentration in the atmosphere $\left(\mathrm{CO}_{2}\right)$, because of different combustion processes of different materials, means that there is a greater absorption of infrared radiation escapes off the earth, which causes an increase in the atmosphere temperature and in the Earth's temperature, causing the ice caps to melt and a greenhouse effect. Acid rain, destruction of the ozone layer and smog are problems associated with air pollution. But it is at the local level where pollution control is important, especially to the people. It is important to know the standard values of air quality. Dust, fiber, soot, fumes, mist, fog, haze and smog (the union of both the smoke haze and photo chemical due to solar radiation), load the environment so that these particles greater or lesser degree affecting not only the health of individuals, but also the visibility and environmental degradation.

The $\mathrm{CO}_{2}$ in natural proportions is not harmful, but as mentioned above, as a result of the combustion of fossil fuels, the concentration in the atmosphere is increasing, become a pollutant greenhouse gas. Other pollutants that directly affect health are: i) Carbon monoxide (CO), mainly associated with traffic and the effect on man is the interference of oxygen transport in the blood, causing intoxication and whose symptoms are drowsiness, headache, fatigue, dysfunction in the central nervous system, heart and lung, followed by coma, respiratory failure and ultimately death; ii) Sulphur dioxide $\left(\mathrm{SO}_{2}\right)$, associated with the combustion of coal and petroleum products. The effect in man focuses on respiratory and whose symptoms are irritation of nose and throat, runny nose, breathing problems, pulmonary edema and death; iii) Nitrogen oxides $\left(\mathrm{NO}_{\mathrm{x}}\right)$, associated with the combustion of fossil fuels, with the effect in humans reducing blood oxygen transport to a lesser extent than the CO and inflammation of lung tissue; iv) Suspended particles, called aerosols, are particles depending on their size can be inhaled (deleted by mucus) or respirable. It influences the formation of sulfurous smog; v) Hydrocarbons $\left(\mathrm{CH}_{\mathrm{x}}\right)$, substances that contain only hydrogen and carbon and influences the formation of photochemical smog; vi) Lead (Pb), toxic element affecting the hematopoietic, nervous system and kidney.

The union of the concentration of pollutants in the atmosphere, the weather and the topographical conditions are the problem of air pollution, where we must pay attention to the source of the contaminant, to the proper contaminant and to the receptor of pollution when it is dispersed. All these affects the health of human beings, but also fossil fuels can be a source of conflict between neighboring countries and even between neighboring cities, due to contamination by toxic gas emissions to a less polluted area. Energy production, energy consumption, the PM10 pollution index, life expectancy, deaths from emissions, $\mathrm{CO}_{2}$ emissions, to clean the environment and the relationship between population and area, are the main indicators to be treated in this paper.

We performed a study on megacities and countries ranging from the poorest to the richest in the world, considering that most populous places with small technology to less populated places with highest technology, also considering the area in km2 of each city and country. Besides the countries which contains mega-cities, other countries that have been analyzed in this paper are: Saudi Arabia, Azerbaijan, Bahrain, Belgium, Brunei Darussalam, Canada, United Arab Emirates, Finland, Iceland, Kazakhstan, Kuwait, Luxembourg, Malaysia, Norway, Oman, Qatar, Singapore, Turkmenistan and Uzbekistan. The megacities studied are collected in Table 4.

The indicators used in this paper for estimating the effects of pollution on health are those indicated below: i) Population density, is the ratio between the population and the urban area or country. A high value indicates a higher concentration of inhabitants per km2, which leads to a mass per unit area and greater possibility of contamination per 
capita, especially in less developed or emerging countries, because they could use more dirty energy for consumption. Turn to be more exposed to contamination risk to health is higher, and increased risk of mortality. In fossil fuel producing countries, a high value indicates that although there is high technology, the level of contamination is high. The processes of production and distribution are the major cause of environmental emissions, followed by the transport and the use of energy industries, businesses, institutions and homes. In developed countries, a high value indicates a high technology and low emissions, as there are no industries that require combustion of fossil fuels. The crowds here are usually temporary, the most important being the risk of $\mathrm{CO}_{2}$ emissions due to traffic. In Table 5, it listed some megacities with a high population density.

Table 4. Population of the agglomerations analysed

\begin{tabular}{|c|c|c|c|}
\hline $\begin{array}{l}\text { Agglomerations ordered by popu- } \\
\text { lation }\end{array}$ & $\begin{array}{l}\text { Population } 2015 \\
\text { (millions) }\end{array}$ & $\begin{array}{c}\text { Agglomerations } \\
\text { ordered by population }\end{array}$ & $\begin{array}{l}\text { Population } 2015 \\
\text { (millions) }\end{array}$ \\
\hline TOKYIO-YOКОНАМА & 37.126 & TIANJIN & 13.266 \\
\hline CHONGQUING & 29.101 & RIO JANEIRO & 12.700 \\
\hline JAKARTA & 28.019 & LAHORE & 12.500 \\
\hline GUANGZHOU & 25.800 & PARIS & 11.940 \\
\hline SHANGHAI & 25.700 & KOLN-RUHR & 11.215 \\
\hline SEOUL & 25.600 & CHENGDU & 11.001 \\
\hline MEXICO & 24.178 & IZMIR & 10.046 \\
\hline DELHI & 23.500 & NAGOYA & 10.027 \\
\hline MUMBAI & 22.376 & WUHAN & 10.020 \\
\hline KARACHI & 22.100 & HARBIN & 9.874 \\
\hline NEW YORK & 22.000 & CHICAGO & 9.800 \\
\hline METRO-MANILA & 21.951 & KINSHASA & 9.518 \\
\hline BEIJING & 21.900 & LIMA & 9.400 \\
\hline SAO PAULO & 21.100 & CHENNAI & 9.182 \\
\hline CAIRO & 20.384 & BANGALURU & 9.044 \\
\hline LOS ANGELES & 18.100 & BOGOTA & 9.009 \\
\hline OSAKA-КОВE & 17.550 & & \\
\hline MOSKOW & 17.000 & MILAN & 8.014 \\
\hline KOLKATA & 15.835 & JOHANNESBURG & 7.900 \\
\hline DHAKA & 15.414 & HONG KONG & 7.134 \\
\hline SHENZHEN & 15.250 & MADRID & 6.600 \\
\hline LONDON & 15.211 & SINGAPORE & 6.500 \\
\hline BANGKOK & 14.566 & TORONTO & 5.900 \\
\hline BUENOS AIRES & 14.300 & SYDNEY & 4.700 \\
\hline ISTANBUL & 13.855 & FRANKFURT & 4.323 \\
\hline TEHRAN & 13.500 & AMSTERDAM-ROTT & 3.004 \\
\hline LAGOS & 13.400 & ZURICH & 1.470 \\
\hline
\end{tabular}

Source: United Nations-Habitat and Price Waterhouse Cooper. 
Table 5. Megacities with high population density

\begin{tabular}{cc}
\hline CITY & POP/S $\left(\mathrm{Hab} / \mathrm{Km}^{2}\right)$ \\
\hline MANILA* & $14,882,03$ \\
LAGOS* & $13,400,00$ \\
BANGALORE** & $12,205,13$ \\
DELHI* & $12,094,70$ \\
CAIRO** & 11927,44 \\
SEOUL*** & $11,541,93$ \\
TEHRAN* & $10,596,54$ \\
DHAKA* & $10,535,88$ \\
IZMIR* & $9,706,28$ \\
KOLKATA* & $8,391,62$ \\
LAHORE* & $7,054,17$ \\
\hline
\end{tabular}

*Cities in development process; **Emerging Cities; ***Developed Cities.

Source: World Bank Data.

It is noted that in the case of Manila, Lagos, Delhi, Bangalore, Cairo, Dhaka or Tehran population density is very high, being between megacities and developed process emerging, fulfilling the first case. Seoul's case is peculiar, since there is high level of contamination, and a high concentration of inhabitants per $\mathrm{km}^{2}$ (See Figure 1).

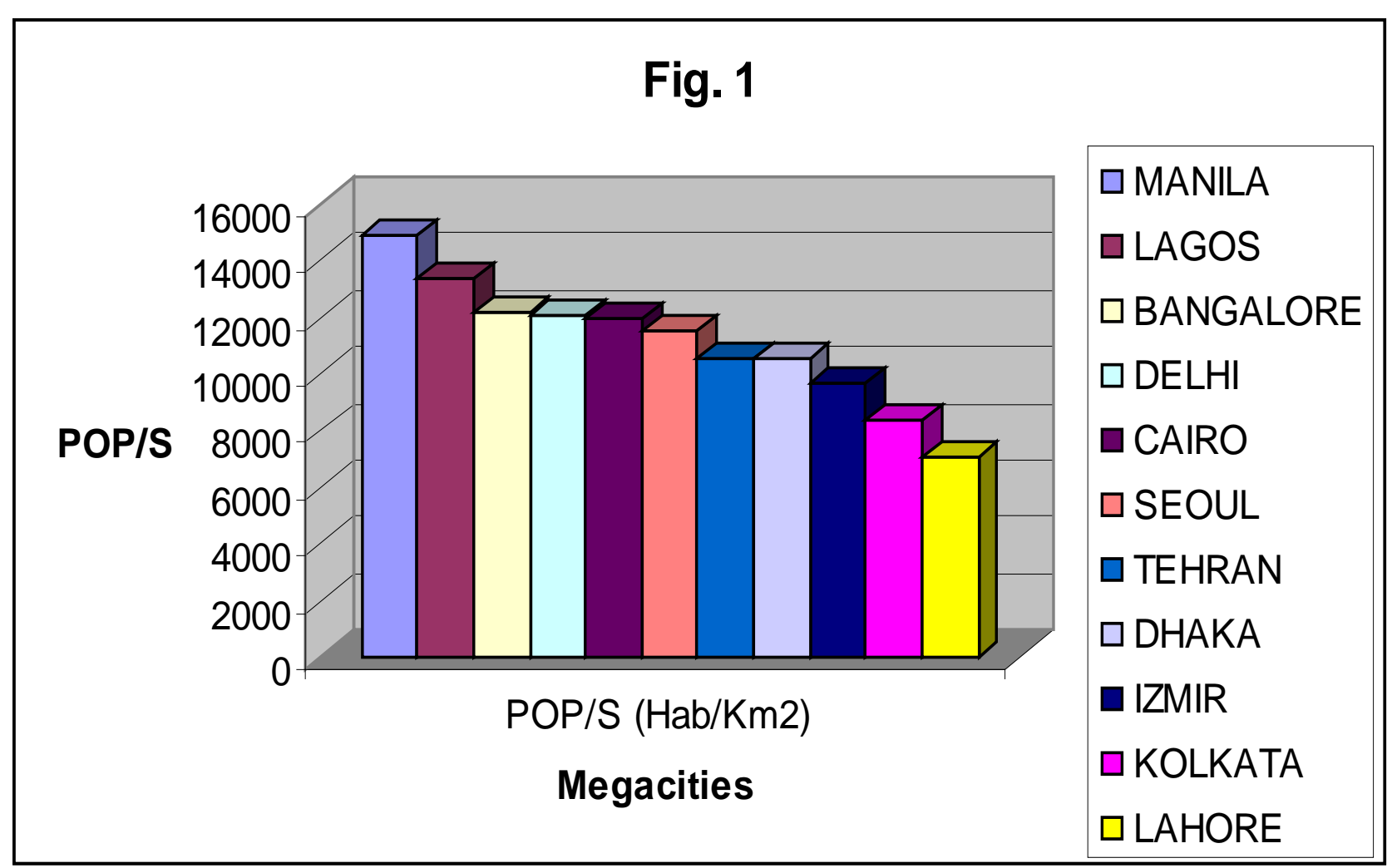

Figure 1. Megacities with high population density (Source: own elaboration). 
Table 6. Megacities with low population density

\begin{tabular}{cc}
\hline CITY & POP/S $\left(\mathrm{Hab} / \mathrm{Km}^{2}\right)$ \\
\hline BEIJING*** & $1,334,47$ \\
WUHAN*** & $1,179,51$ \\
TIANJIN*** & $1,128,06$ \\
KINSHASA* & 955,14 \\
CHENGDU** & 906,77 \\
NEW YORK**** & 717,31 \\
PARIS**** & 695,23 \\
CHONGQING** & 353,15 \\
CHICAGO**** & 348,50 \\
L ANGELES**** & 206,88 \\
HARBIN*** & 185,95 \\
\hline
\end{tabular}

${ }^{*}$ Cities in development process; **Emerging Cities; ***Developed Cities; ****High Developed Cities.

Source: World Bank Data.

This may be due to the use of other energy sources alternative such as nuclear, which employs about $18 \%$ of the total energy produced. Some megacities with low population density are below in Table 6 and Figure 2.

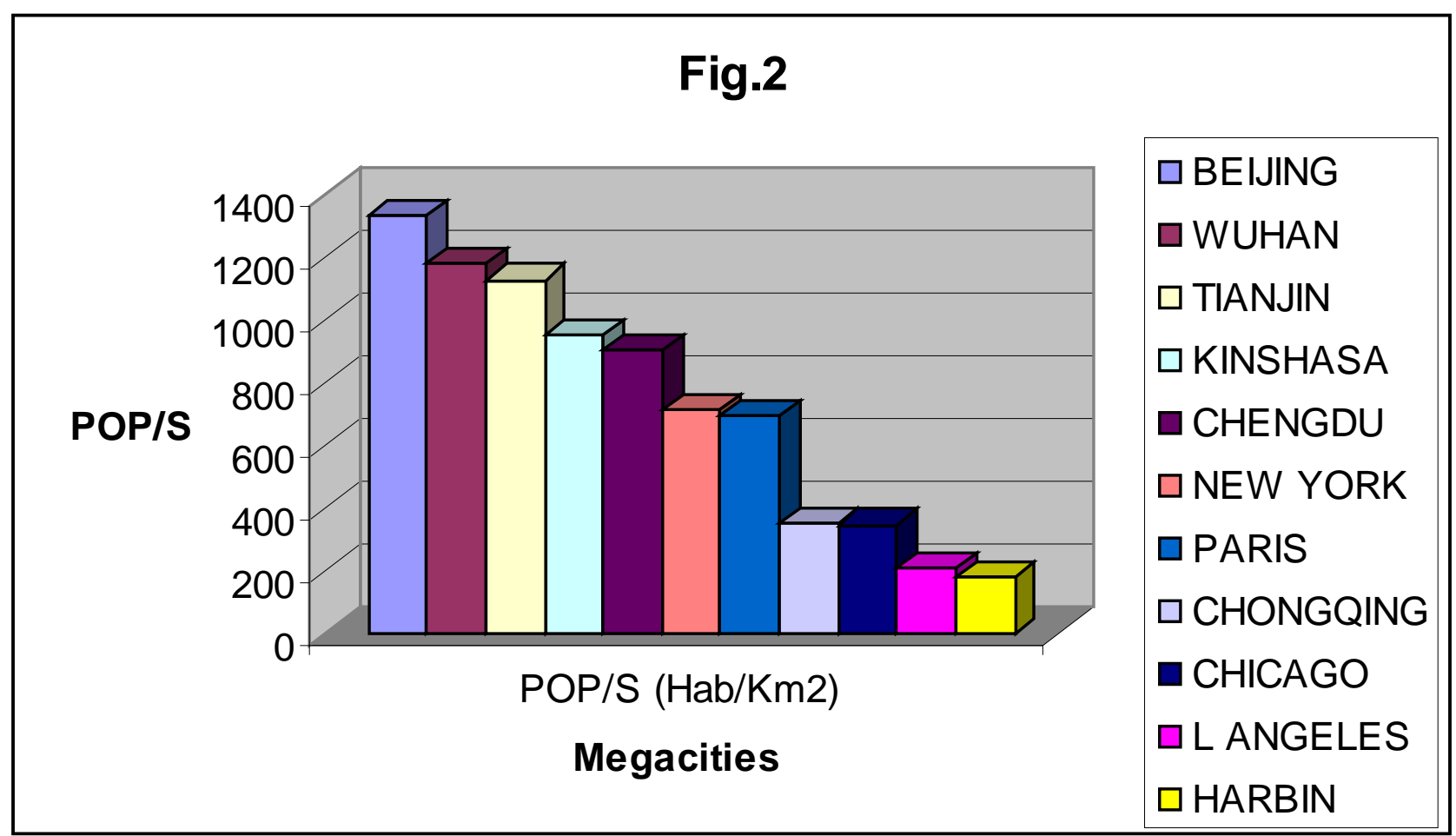

Figure 2. Megacities with low population density (Source: own elaboration).

In this case, it appears that less-developed or emerging megacities have a very low population density, because they have a large area, despite having more than 9 million people. This does not indicate that pollutes less, but has much more surface to pollute. The most developed cities like Los Angeles, Chicago, Paris or NewYork, have a hightech and less pollution index, mainly due to traffic and some industries outside the urban core. Countries like Bangladesh, South Korea, India, Japan and Bahrain are overcrowded and coverall ranges of development. 
Conversely if you have a small population country like Iceland with 3.0 inhabitants per square kilometer, Canada with 3.3Inh/ $/ \mathrm{Km}^{2}$, Oman, Norway, Finland and Brunei, all with apopulation density of less than 100Inh/Km2. ii) PM10, particulate matter, are small solid or liquid particles of dust, ashes, soot, metal particles, cement or pollen dispersed in the atmosphere. The PM10 includesvalues lessthan 10 microns (micrometers). The daily limit value for the protection of human healthis $50 \mathrm{ug} / \mathrm{m}^{3} \mathrm{PM} 10$ not to be exceeded more than 7 times per year and the annual limit value for the protection of human health is $20 \mathrm{ug} / \mathrm{m}^{3}$. Megacities of further development are most close to the limit of PM10, which could be interpreted as the safest places for health and are indicated in the following Table 7:

Table 7. No air pollution Megacities

\begin{tabular}{cc}
\hline CITY & PM1O \\
\hline MOSCOW** $^{* *}$ & 33 \\
SAO PAULO* & 38 \\
PARIS*** & 38 \\
B. AIRES** & 38 \\
NEW YORK*** & 21 \\
L ANGELES*** & 25 \\
LONDON*** & 29 \\
KOLNRUHR $^{* *}$ & 23 \\
TOKYO** & 23 \\
CHICAGO*** & 22 \\
OSAKA $* *$ & 27 \\
\hline
\end{tabular}

*Emerging Cities; **Developed Cities; ***High Developed Cities.

Source: World Bank Data.

If the PM10 limit is exceeded, it may imply a less developed technology, being very harmful to health and, therefore, life expectancy will be lower (See Table 8).

Table 8. Air pollution Megacities

\begin{tabular}{cc}
\hline CITY & PM1O \\
\hline DHAKA* & 134 \\
LAGOS* & 122 \\
CAIRO** & 138 \\
KARACHI* & 193 \\
KOLKATA* & 148 \\
MUMBAI** & 132 \\
BEIJING*** & 121 \\
DELHI** & 198 \\
LAHORE* & 200 \\
CHONGQING** & 105 \\
CHENGDU & 111 \\
\hline
\end{tabular}

*Cities in development process; **Emerging Cities; ***Developed Cities.

Source: World Bank Data.

For countries that have an index close to PM10 limit are Russia, Brazil, France, Argentina, U.S., UK, Germany, 
Japan, Iceland, Finland, Norway, Belgium, Canada, Luxembourg and Malaysia. The highest PM10 countries are Pakistan, Bangladesh, Nigeria, Egypt, India, China, Saudi Arabia, UAE and Kuwait, this latter, associated with the production and distribution of fossil fuels.

\section{Conclusions}

This research has proposed a microeconomic model that explains the supply and demand of energy, energy consumption and emissions produced by energy consumption and economic activity in the economic equilibrium. The objective of this model is to find from the economic theory causal relationships between energy consumption and economic activity and between emissions and energy consumption. The emissions covered by this research are exclusively those of carbon dioxide, which was selected as the most abundant greenhouse gas and supposedly the most responsible for global warming and therefore of the possible long-term environmental degradation. The most important purpose of this research is to analyse what part of the total carbon dioxide emissions is associated with energy consumption and which part is associated with economic activity, regardless of energy consumption.We can conclude, then, that one of the most important reasons in the emissions of polluting gases is the total production of economic activity, above the consumption of energy. There is a commitment in the Asian countries to reduce the consumption of fossil fuels and to invest in renewable energies or even to recycle pollutants, converting them into heat or using other technologies to cleanse these pollutants. The main conclusions on the sources of conflicts are the energy dependence between neighbouring countries or cities, $\mathrm{CO}_{2}$ emissions to a neighbouring country or city, and the neighboring countries with different levels of development. As to the impact of emissions, the impact on health, especially in the respiratory tract and blood oxygen, the environmental impact and the emissions cause conflicts in neighbouring countries. Finally, on the solutions of conflicts, we must reach a compromise for reduce $\mathrm{CO}_{2}$ emissions, if possible, it is necessary to reduce fossil energy (coal and oil) using a convenient treatment in the production, recycling the gases expelled and augmenting the use of renewable energy (non-dependence between countries).

\section{References}

Abosedra, S. and Baghestani, H. (1989). "New evidence on the causal relationship between United States energy consumption and gross national product”. Journal of Energy Development, Vol. 14, pp. 285-292.

Alam, M., Begum, I., and Buysse, J. (2012). "Energy consumption, carbon emissions and economic growth nexus in Bangladesh: cointegration and dynamic causality analysis”. Energy Policy, Vol. 45, pp. 217-225.

Altinay, G. and Karagol, E. (2004). "Structure break, unit root, and the causality between energy consumption and GDP in Turkey”. Energy Economy, Vol. 26, pp. 985-994.

Ang, J. (2007a). “Economic development, pollutant emissions and energy consumption in Malaysia”. Journal of Policy Modelling, Vol. 30, pp. 271-278.

Ang, J. (2007b). “ $\mathrm{CO}_{2}$ emissions, energy consumption, and output in France”. Energy Policy, Vol. 35, pp. 4772-4778.

Aspergis, N. and Payne, J. (2009). “CO2 emissions, energy usage, and output in Central America”. Energy Policy, Vol. 37, pp. 3282-3286.

Belloumi, M. (2009). "Energy consumption and GDP in Tunisia: cointegration and causality analysis”. Energy Policy, Vol. 37, pp. 2745-2753.

Caballero, K. and Galindo, L. (2007). "El consumo de energía en México y sus efectos en el producto y los precios”. Problemas del Desarrollo Revista Latinoamericana de Economía, Vol. 38, pp. 127-151.

Cheng, B. (1997). "An investigation of co-integration and causality between energy consumption and economic activity in Taiwan”. Energy Economics, Vol. 19-4, pp. 435-444.

Deaton, A., Muellbauer, J. (1980). “An almost ideal demand system”. American Economic Review, 70(3), 312-326.

Farhani, S. and Ben Rejeb, J. (2012). "Link between economic growth and energy consumption in over 90 countries”. Interdisciplinary Journal of Contemporary Research in Business, Vol. 3-11, pp. 282-297.

Gardner, T. and Joutz, F. (1996). "Economic growth, energy prices and technological innovation”. Southern Economic Journal, Vol. 62-3, pp. 653-666.

Ghali, K. (2004). Energy use and output growth in Canada: A multivariate cointegration analysis”. Energy Economics, Vol. 26-2, pp. 225-238.

Gómez, C. (2010). Crecimiento económico, consumo de energía y emisiones contaminantes en la economía mexicana”. 
Revista Fuente, Vol. 3-9, pp. 67-80.

Halicioglu, F. (2009). “An econometric study of CO2 emissions, energy consumption, income and foreign trade in Turkey”. Energy Policy, Vol. 37, pp. 1156-1164.

Hettige, H., Mani, M., and Wheeler, D. (2000). "Industrial pollution in economic development: the environmental Kuznets curve revisited”. Journal of Development Economics, Vol. 62, pp. 445-476.

International Energy Agency. (2016). International Energy Outlook, U.S. Department of Energy, Washington, DC.

IPCC. (2018). Global Warming of $1.5^{\circ} \mathrm{C}$, Special Report. Intergovernmental Panel on Climate Change, New York.

Jobert, T. and Karanfil, F. (2007). "Sectoral energy consumption by source and economic growth in Turkey”. Energy Policy, Vol. 35-11, pp. 5447-5456.

Kraft, J. and Kraft, G. (1978). “On the relationship between energy and GNP”. Journal of Energy Development, Vol. 3, pp. 401-403.

Labandeira, X., Labeaga, J. M., and López-Otero, X. (2017). "Elasticities of transport fuels at times of economic crisis: An empirical analysis for Spain”. Energy Economics, Vol. 68, pp. 66-80.

Luzzati, T. and Orsini, M. (2009). "Investigating the energy-environmental Kuznets curve”. Energy, Vol. 34, pp. 291-300.

Mallick, H. (2009). "Examining the linkage between energy consumption and economic growth in India”. The Journal of Developing Areas, Vol. 43-1, pp. 249-280.

Medlock, K. and Soligo, R. (2001). "Economic development and end-use energy demand”. The Energy Journal, Vol. 22-2, pp. 77-105.

Mehara, M. (2007). "Energy consumption and economic growth: The case of oil exporting countries". Energy Policy, Vol. 35, pp. 2939-2945.

Pao, H. and Tsai, C. (2010). “ $\mathrm{CO}_{2}$ Emissions, energy consumption and economic growth in BRIC countries”. Energy Policy, Vol. 38, pp. 7850-7860.

Price Waterhouse Cooper. (2012). Cities of the Future: Global Competition, Local Leadership, PWC.

Razzaqui, S., Bilquees, F., and Sherbaz, S. (2011). "Dynamic relationship between energy and economic growth: Evidence from D8 countries”. The Pakistan Development Review, Vol. 50-4, pp. 437-458.

Siddiqui, R. (2004). "Energy and economic growth in Pakistan”. The Pakistan Development Review, Vol. 43-2, pp. $175-200$.

Soytas, U., Sari, R., and Ewinng, B. (2007). "Energy consumption, income, and carbon emissions in the United States”. Ecological Economics, Vol. 62, pp. 482-489.

Srinivasan, P. and Siddanth, I. (2015). "Causality among energy consumption, $\mathrm{CO}_{2}$ emission, economic growth and trade: A case of India”. Foreign Trade Review, Vol. 50-3, pp. 168-189.

Tsani, S. (2010). "Energy consumption and economic growth: A causality analysis for Greece”. Energy Economics, Vol. 32-3, pp. 582-590.

Yu, E. and Jin, J. (1992). “Cointegration tests of energy consumption, income, and employment”. Resources and Energy, Vol. 14-3, pp. 259-266.

Zamani, M. (2007). "Energy consumption and economic activities in Iran”. Energy Economics, Vol. 29-6, pp. 1135-1140.

Zhang, X. and Cheng, X. (2009). “Energy consumption, carbon emissions, and economic growth in China”. Ecological Economics, Vol. 68, pp. 2706-2712.

Zhang, Y. (2011). "Interpreting the dynamic nexus between energy consumption and economic growth: Empirical evidence from Russia”. Energy Policy, Vol. 39-5, pp. 2265-2272. 